\section{London Zoo crippled}

SIR - Your leading article (Nature 357, 613 ; 1992) repeats familiar but unsubstantiated charges against the council of the Zoological Society of London. As Lord Zuckerman points out in the same issue $(357,621$; 1992), cash flow problems began in the 1960 s and continued through to the 1980s. Acknowledging London Zoo's status as a national institution, government gave occasional grants to restore operating losses, while other national zoos received large annual subsidies. The zoo management has never been perfect but few if any capital zoos can match London's record of raising 80 per cent of its costs from visitor revenues.

You ignore Zuckerman's clear statement that the 1988 settlement of $£ 10$ million from the government was conditional upon acceptance of a new management with, as you say, "an entrepreneurial cast of mind". The council had little part in this - even the chief executive was chosen by the government.

As for pricing ourselves out of the market, where else can you get a full day out for $\mathfrak{f 6}$, the price of a cinema seat? The Report on London Zoo published by the Select Committee on the Environment in June 1991 gives comparative entrance prices for other visitor attractions and London Zoo is shown to be highly competitive. Few zoos today make a profit, and it is disingenuous to make unfavourable comparisons with provincial zoos whose situation is utterly different.

Like many commentators, you seem to equate London Zoo with the Zoological Society. Much as we all wish the zoo to survive, it is not indispensable for the work of the learned society, the library, the scientific meetings, publications, the research laboratories and of course Whipsnade. It is much to the credit of the government that it appreciated the distinction in 1988 and guaranteed an annual grant of $£ 1.3$ million (indexed) to support the research of the Institute of Zoology four years before biodiversity became a political byword.

Barry Cross

(Secretary)

Zoological Society of London,

Regent's Park, London NW1 4RY, UK

\section{No connection}

SIR - There is much talk these days of irresponsible and misleading reporting in the media and I had not imagined that I should be writing to level such a charge against Nature. But your leading article "Leeds Disunited" (357, 614; 1992) leaves me no option. It refers to an allegation about scientific misconduct reported to me last September that led ultimately to an investigation by a trio of eminent scientists, two from this university and one from an internationally renowned medical school in London. The panel followed guidelines modelled on those recommended by the Royal College of Physicians and it reported in March. The essence of the Royal College guidelines is that any such inquiry should be confidential.

In the event, the panel reported that the balance of evidence supported the view that there had been fraud (albeit of a minor nature) by a junior scientist and I wish to say only that appropriate action has been taken by the university. As far as we are concerned, the matter ends there.

Any attempt to relate this incident by inference to the entirely separate situation at Leeds General Infirmary betrays a post hoc ergo propter hoc style of reasoning that I would have thought inimical to the scientific standards espoused by your journal. The remarks in the last paragraph of your leading article are likely to work against the scientists whose integrity you appear to wish to protect.

\section{J. J. Walsh}

(Registrar)

The University, Leeds LS2 9JT, UK

\section{Nonpersons}

SIR - If we are led to believe (Nature $357,425 ; 1992)$ that an eight-cell blastomere cannot be considered a person, then as a Christian I believe this to be totally incompatible with the biblical text concerning the Incarnation. To suggest that God become man at some arbitrary future date would be ridiculous.

\section{Anthony Gannon}

Division of Quantum Metrology,

National Physical Laboratory,

Teddington, Middlesex, UK

\section{Journalists in labs}

SIR - Jonathan Stamford (Nature 357, 10 ; 1992) comments on the need to find means of placing journalists in suitable laboratories for a period of weeks, so that they "might then appreciate not only how scientists think and interact but the nature of the research process".

Your readers will be interested to learn that a programme designed to do exactly what Stamford suggests will be initiated in April 1993 at the Max Planck Institutes of Biochemistry and Psychiatry in Munich, with the endorsement of the
European Communities, the Committee on the Public Understanding of Science, the Max Planck Society and similar highlevel research agencies in the major European countries. The programme is called EICOS (European Initiative for Communicators of Science) and will be open to established science reporters from all the countries of Europe and all branches of the media (newspapers, magazines, radio, television and freelance), as well as to editors and broadcast producers.

Byron H. Waksman

(Program Director, EICOS)

Science Writing Fellowships Program,

Marine Biological Laboratory,

Woods Hole, Massachusetts 02543, USA

\section{Einstein's beliefs}

SIR - Many people asked Albert Einstein about his religious views and I, when a US Navy ensign in 1945, was one of them. On 2 July 1945, in response to a letter from me quoting an acquaintance who claimed that a Jesuit priest had convinced Einstein that a supreme intellect governs the Universe, Einstein denied ever having spoken to a Jesuit priest and said: "From the viewpoint of a Jesuit priest I am, of course, and have always been an atheist.. .."

Five years later, on 25 September 1949, I wrote again: “. . . [In your letter,] You say that 'From the viewpoint of a Jesuit priest I am, and have always been, an atheist'. Some people might interpret that to mean that to a Jesuit priest, anyone not a Roman Catholic is an atheist, and that you are in fact an orthodox Jew, or a Deist, or something else. Did you mean to leave room for such an interpretation, or are you from the viewpoint of the dictionary an atheist; i.e. 'one who disbelieves in the existence of a God, or Supreme Being?'. . ."

Einstein's response, dated 28 September 1949, says:“. . . I have repeatedly said that in my opinion the idea of a personal God is a childlike one. You may call me an agnostic, but I do not share the crusading spirit of the professional atheist whose fervor is mostly due to a painful act of liberation from the fetters of religious indoctrination received in youth. I prefer an attitude of humility corresponding to the weakness of our intellectual understanding of nature and of our own being."

Guy H. Raner Jr

22244-2 James Alan Circle,

Chatsworth, California 91311-7137, USA

with the assistance of

Lawrence $\mathbf{S}$. Lerner

Department of Physics and Astronomy, California State University, Long Beach.

Long Beach, California 90840, USA 